\title{
Effect of Organic and Inorganic Sources of Nutrients on Secondary and Micro Nutrient Uptake by Rice at various Growth Periods
}

\author{
Mohana Rao Puli, P R K Prasad, *B Srihari Rao and **M Jayalakshmi \\ Department of Soil Science and Agricultural Chemistry, Agricultural College, Bapatla, Andhra Pradesh, India \\ *BCT Krishi Vigyan Kendra, Vizag, Telangana, India \\ **Central Research Institute for Dryland Agriculture, Hyderabad - 500 070, Telangana, India \\ e-mail: mohanpulioo7@gmail.com
}

Received: 04 March 2016; Revised accepted: 30 December 2016

\section{A B S T R A C T}

A field experiment was conducted for two consecutive years (2011-2012 and 2012-2013) on fine texture soils of Agricultural College Farm, Bapatla to find out the effect of different sources of nutrients on secondary ( $\mathrm{Ca}$ and $\mathrm{Mg}$ ) and micro nutrient ( $\mathrm{Fe}, \mathrm{Mn}, \mathrm{Cu}$ and $\mathrm{Zn}$ ) uptake by rice at various growth periods. The experiment was laid out in a randomized block design in kharif season with four treatments and replicated five times. The treatments consisted of $M_{1}$ (RDF- Control), $M_{2}$ (10t FYM ha $\left.{ }^{-1}+R D F\right), M_{3}$ (1.5t vermicompost ha $\left.{ }^{-1}+R D F\right), M_{4}$ (Green manuring + RDF). The nutrient content in rice at various growth periods was significantly increased with the application of $100 \%$ NPK in combination with FYM @ 10t ha ${ }^{-1}$. However, it was on par with that of green manuring together with $100 \%$ NPK during both the years of the study.

Key words: Micro nutrients, Rice crop, Organic sources, Secondary nutrients, Growth periods

$\mathrm{C}$ ultivation of high yielding crop varieties and multiple cropping is depleting the fertility of soils at a rapid pace. The soils, which were, once well supplied with available nutrients, are now gradually becoming deficient (Zia et al. 1994). Soil organic matter encourages granulation, increases cation exchange capacity (CEC) and is responsible for adsorbing power of the soils up to $90 \%$. Cations such as $\mathrm{Ca}^{2+}, \mathrm{Mg}^{2+}$ and $\mathrm{K}^{+}$are produced during decomposition (Brady 1990). Use of compost can be beneficial to improve organic matter status. Compost is rich source of nutrients with high organic matter content. Physical and chemical properties of soil can be improved by using compost, which may ultimately increase crop yields. So use of compost is the need of the time. Physical properties like bulk density, porosity, void ratio, permeability and hydraulic conductivity were significantly improved when FYM $\left(10 \mathrm{tha}^{-1}\right)$ was applied in combination with chemical amendments, resulting in enhanced rice and wheat yields in sodic soil (Hussain et al. 2001).

Addition of organic materials like FYM and sunnhemp increases the availability of micronutrients (Bellakki and Badanur 1997). The increased availability was attributed to enhanced microbial activity in the soil and the consequent release of complex organic substances that could have prevented micronutrients from precipitation, fixation, oxidation and leaching and also addition of these nutrients through organic sources. The unbalanced use of $\mathrm{N}$ fertilizers has at times led to environmental confrontations, disturbance in soil nutrient balance and depletion of soil fertility. Even the introduction of high yielding varieties and intensive cultivation with excess and imbalanced use of chemical fertilizers and irrigation showed reduction in the soil fertility status and yield by 38 per cent of rice crop (Singh et al. 2001).

\section{MATERIALS AND METHODS}

In order to investigate the influence of different sources of nutrients on micronutrient content in rice, the present experiment was conducted in the field number 49A and 49B of the Agricultural College Farm, Bapatla, during the years 2011-12 and 2012-13, respectively. Prior to preparatory cultivation of the experimental site, soil samples from 0 to $15 \mathrm{~cm}$ depth were collected at random and a composite soil sample during both the years was analyzed for different physico-chemical properties. The results of the soil analytical data indicated that the experimental soil is clay and sandy clay during first and second year, respectively in texture, slightly alkaline in reaction, low in organic carbon ( 0.52 and $0.50 \%$ during first and second year, respectively) and available nitrogen (175.6 and $159.8 \mathrm{~kg} \mathrm{ha}^{-1}$ during first and second year, respectively), and high in available phosphorus (95.3 and $93.9 \mathrm{~kg} \mathrm{P}_{2} \mathrm{O}_{5} \mathrm{ha}^{-1}$ during first and second year, respectively) and potassium (960.0 and 925.6 $\mathrm{kg} \mathrm{K}_{2} \mathrm{O} \mathrm{ha}^{-1}$ during first and second year, respectively). The 
experiment consisted of four treatments viz. $\mathrm{M}_{1}$ (RDF Control), $\mathrm{M}_{2}$ (10t FYM ha $\left.{ }^{-1}+\mathrm{RDF}\right), \mathrm{M}_{3}$ (1.5t vermicompost $\left.\mathrm{ha}^{-1}+\mathrm{RDF}\right), \mathrm{M}_{4}$ (Green manuring $\left.+\mathrm{RDF}\right)$. The experiment is laid out in RBD and replicated five times. The recommended fertilizer dose was applied as 160:40:40kg N, $\mathrm{P}_{2} \mathrm{O}_{5}$ and $\mathrm{K}_{2} \mathrm{O}$ ha $^{-1}$. A popular super fine rice cultivar BPT 5204 (Samba Mashuri) was selected for kharif season. It is a cross between (GEB-24 $\times$ TN-1) and Mashuri. FYM and vermicompost were added 7 days before transplanting of rice on dry weight basis. Dhaincha crop was raised with the seed rate of $60 \mathrm{~kg} \mathrm{ha}^{-1}$ in individual plots and it was incorporated 7 days before transplanting of rice as green manure at flowering stage. Nitrogen was applied in the form of urea in three splits, first split at the time of transplanting, second split at 30 DAT and third split at 60 DAT. Phosphorus was applied in the form of SSP as basal dose before transplanting. Potassium was applied in the farm of MoP in two splits, first split as basal before transplanting and second split. Plant samples of rice and maize were collected from five randomly selected plants at harvest stage. The samples were first dried in shade and then in hot air oven at $65^{\circ} \mathrm{C}$. The plant samples were ground in willey mill and stored in labeled brown paper bags for analysis.
The grain samples were also processed and stored in similar fashion. Calcium and magnesium were estimated by EDTA method as described by Hesse (1971) in di-acid extract.

\section{Micronutrients ( $\mathrm{Fe}, \mathrm{Mn}, \mathrm{Cu}, \mathrm{Zn}$ )}

$\mathrm{Fe}, \mathrm{Mn}, \mathrm{Cu}, \mathrm{Zn}$ were estimated by using AAS (Lindsay and Norvell 1978) from di-acid extract, from the chemical analytical data, uptake of the each nutrient was calculated as shown below:

$$
\text { Nutrient uptake }\left(\mathrm{kg} \mathrm{ha}^{-1}\right)=\frac{\begin{array}{c}
\text { Nutrient content }(\%) \times \text { dry } \\
\text { weight in } \mathrm{kg} \mathrm{ha}^{-1}
\end{array}}{100}
$$

\section{RESULTS AND DISCUSSION}

\section{Ca uptake by rice}

$\mathrm{Ca}$ is an essential part of cell structure and plays its role in cell division. It is absorbed by the plant in the form of $\mathrm{Ca}^{2+}$ (Tandon 2000). The results of the present study (Table 1) indicated that uptake of $\mathrm{Ca}$ at $30 \mathrm{DAT}, 60 \mathrm{DAT}, 90 \mathrm{DAT}$ and maturity was recorded significantly higher in treatments those received organics along with RDF over RDF alone, during both the years of study.

Table 1 Influence of organics on calcium uptake $\left(\mathrm{kg} \mathrm{ha}^{-1}\right)$ at different growth periods of rice

\begin{tabular}{|c|c|c|c|c|c|c|c|c|c|c|}
\hline \multirow[b]{2}{*}{ Treatment } & \multicolumn{5}{|c|}{$2011-2012$} & \multicolumn{5}{|c|}{$2012-2013$} \\
\hline & $\begin{array}{c}30 \\
\text { DAT }\end{array}$ & $\begin{array}{c}60 \\
\text { DAT }\end{array}$ & $\begin{array}{c}90 \\
\text { DAT }\end{array}$ & Straw & Grain & $\begin{array}{c}30 \\
\text { DAT }\end{array}$ & $\begin{array}{c}60 \\
\text { DAT }\end{array}$ & $\begin{array}{c}90 \\
\text { DAT }\end{array}$ & Straw & Grain \\
\hline $\mathrm{M}_{1}-\mathrm{RDF}$ (Control) & 11.46 & 22.16 & 23.39 & 13.96 & 10.68 & 9.95 & 32.59 & 37.56 & 21.40 & 6.08 \\
\hline $\mathrm{M}_{2}$ - FYM 10t ha ${ }^{-1}+\mathrm{RDF}$ & 19.91 & 38.24 & 34.95 & 20.25 & 15.98 & 15.37 & 44.53 & 49.61 & 32.33 & 10.77 \\
\hline $\mathrm{M}_{3}$ - Vermicompost $1.5 \mathrm{tha}^{-1}+\mathrm{RDF}$ & 16.72 & 33.63 & 30.62 & 18.10 & 13.43 & 12.18 & 38.57 & 45.59 & 26.14 & 8.08 \\
\hline $\mathrm{M}_{4}$ - Green manuring $+\mathrm{RDF}$ & 17.91 & 37.59 & 38.69 & 20.92 & 15.28 & 12.60 & 41.99 & 46.78 & 29.19 & 8.84 \\
\hline $\mathrm{SEm} \pm$ & 0.817 & 1.703 & 1.462 & 0.749 & 0.611 & 0.550 & 1.345 & 1.634 & 0.967 & 0.500 \\
\hline CD (P: 0.05) & 2.52 & 5.25 & 4.50 & 2.31 & 1.88 & 1.70 & 4.14 & 5.03 & 2.98 & 1.54 \\
\hline $\mathrm{CV}(\%)$ & 11.1 & 11.6 & 10.2 & 9.1 & 9.9 & 9.8 & 7.6 & 8.1 & 7.9 & 13.2 \\
\hline
\end{tabular}

There was always a direct relationship between the soil concentration of nutrients and its quantity taken by the plants. During second year of the study calcium uptake at 30 and 60 DAT among the organics applied to rice FYM application@10t ha ${ }^{-1}\left(\mathrm{M}_{2}\right)$ and green manuring $\left(\mathrm{M}_{4}\right)$ was on par. Except at 60 DAT, the Ca uptake by rice in 2011 kharif in all growth stages $\mathrm{M}_{2}$ (application of FYM $+\mathrm{RDF}$ ) showed significant superiority over $\mathrm{M}_{3}$ (vermicompost) whereas, in 2012 kharif, this exception was recorded at 90 DAT. The maximum Ca uptake by rice grain was recorded in the treatment $\mathrm{M}_{2}$ with 15.98 and $10.77 \mathrm{~kg} \mathrm{ha}^{-1}$ followed by $\mathrm{M}_{4}$ with 15.28 and $8.84 \mathrm{~kg} \mathrm{ha}^{-1}$ during first and second year of the study, respectively. The treatment $\mathrm{M}_{2}$ recorded 50.0 and $77.13 \%$ higher $\mathrm{Ca}$ uptake by grain over $\mathrm{M}_{1}$ in 2011 and 2012, respectively. These results were in conformity with the findings of Chander et al. (2007) who observed that the incorporation of FYM resulted in to a significant and consistent increase in Ca uptake by cauliflower. Pattanayak et al. (2001) also reported the highest $\mathrm{Ca}$ uptake in the treatments that received green manuring of dhaincha.

Table 2 Influence of organics on magnesium uptake $\left(\mathrm{kg} \mathrm{ha}^{-1}\right)$ at different growth periods of rice

\begin{tabular}{|c|c|c|c|c|c|c|c|c|c|c|}
\hline \multirow[b]{2}{*}{ Treatment } & \multicolumn{5}{|c|}{ 2011-2012 } & \multicolumn{5}{|c|}{$2012-2013$} \\
\hline & $\begin{array}{c}30 \\
\text { DAT }\end{array}$ & $\begin{array}{c}60 \\
\text { DAT }\end{array}$ & $\begin{array}{c}90 \\
\text { DAT }\end{array}$ & Straw & Grain & $\begin{array}{c}30 \\
\text { DAT }\end{array}$ & $\begin{array}{c}60 \\
\text { DAT }\end{array}$ & $\begin{array}{c}90 \\
\text { DAT }\end{array}$ & Straw & Grain \\
\hline $\mathrm{M}_{1}-\mathrm{RDF}$ (Control) & 3.52 & 11.51 & 13.12 & 7.55 & 9.13 & 2.81 & 12.09 & 13.84 & 6.55 & 7.49 \\
\hline $\mathrm{M}_{2}-\mathrm{FYM} 10 \mathrm{tha} \mathrm{h}^{-1}+\mathrm{RDF}$ & 5.05 & 15.04 & 17.72 & 9.66 & 12.30 & 3.84 & 16.24 & 18.34 & 10.05 & 11.20 \\
\hline $\mathrm{M}_{3}$ - Vermicompost $1.5 \mathrm{tha}^{-1}+\mathrm{RDF}$ & 4.65 & 12.33 & 16.09 & 8.96 & 11.65 & 3.52 & 14.15 & 16.97 & 8.37 & 9.77 \\
\hline $\mathrm{M}_{4^{-}}$Green manuring $+\mathrm{RDF}$ & 4.90 & 13.57 & 17.27 & 9.51 & 12.29 & 3.43 & 14.97 & 17.91 & 9.80 & 10.32 \\
\hline $\mathrm{SEm} \pm$ & 0.174 & 0.459 & 0.427 & 0.245 & 0.480 & 0.117 & 0.669 & 0.796 & 0.397 & 0.470 \\
\hline $\mathrm{CD}(\mathrm{P}: 0.05)$ & 0.53 & 1.42 & 1.31 & 0.76 & 1.48 & 0.36 & 2.06 & 2.45 & 1.22 & 1.45 \\
\hline $\mathrm{CV}(\%)$ & 8.6 & 7.8 & 5.9 & 6.1 & 9.5 & 7.7 & 10.4 & 10.6 & 10.2 & 10.8 \\
\hline
\end{tabular}


Mg uptake by rice

$\mathrm{Mg}$ is an integral part of chlorophyll and thus is linked with photosynthesis. In plant tissues it is absorbed in the form of $\mathrm{Mg}^{+2}$. It plays an important role in energy transfer processes in plants (Tandon 2000). Results pertaining in the (Table 2) reviewed that irrespective of growth stage of rice and year of the study the treatments those received organics along with the RDF $\left(\mathrm{M}_{2}, \mathrm{M}_{3}\right.$ and $\left.\mathrm{M}_{4}\right)$ significantly increased the $\mathrm{Mg}$ uptake over the treatment that received RDF alone $\left(\mathrm{M}_{1}\right)$. The uptake of $\mathrm{Mg}$ by rice plant was highest when fertilizer was applied in combination with vermicompost (Jadhav et al. 1997). The highest Mg uptake by rice during both years of study was recorded in the treatment $\mathrm{M}_{2}$ with $5.05,15.04$ and $17.72 \mathrm{~kg} \mathrm{ha}^{-1}$ at 30,60 , and $90 \mathrm{DAT}$, respectively in 2011 followed by $\mathrm{M}_{4}$ in all growth stages of rice (Table 2). Pattanayak et al. (2001) reported that $\mathrm{Mg}$ uptake was the highest in the treatments those received green manuring of dhaincha. The salts of $\mathrm{Ca}$ and $\mathrm{Mg}$ are relatively less soluble, therefore leaching of $\mathrm{Ca}$ and $\mathrm{Mg}$ could be less. Hence the concentration of these nutrients in the soil solution is relatively higher from where the plants absorbed them in more quantities. Mg uptake by grain and straw also followed the same trend of different growth stages. All the organics were on par with each other regarding $\mathrm{Mg}$ uptake. The treatment $\mathrm{M}_{2}$ had recorded 34.7 and $27.9 \%$ higher $\mathrm{Mg}$ uptake by rice grain and straw respectively in 2011 kharif over $\mathbf{M}_{1}$. These results were in close agreement with the findings of Karmakar et al. (2010).

Table 3 Influence of organics on iron uptake $\left(\mathrm{kg} \mathrm{ha}^{-1}\right)$ at different growth periods of rice

\begin{tabular}{|c|c|c|c|c|c|c|c|c|c|c|}
\hline \multirow[b]{2}{*}{ Treatment } & \multicolumn{5}{|c|}{$2011-2012$} & \multicolumn{5}{|c|}{$2012-2013$} \\
\hline & $\begin{array}{c}30 \\
\text { DAT }\end{array}$ & $\begin{array}{c}60 \\
\text { DAT }\end{array}$ & $\begin{array}{c}90 \\
\text { DAT }\end{array}$ & Straw & Grain & $\begin{array}{c}30 \\
\text { DAT }\end{array}$ & $\begin{array}{c}60 \\
\text { DAT }\end{array}$ & $\begin{array}{c}90 \\
\text { DAT }\end{array}$ & Straw & Grain \\
\hline $\mathrm{M}_{1}-\mathrm{RDF}$ (Control) & 0.75 & 3.00 & 3.96 & 2.52 & 0.84 & 0.71 & 3.43 & 4.38 & 2.61 & 0.77 \\
\hline $\mathrm{M}_{2}-\mathrm{FYM} 10 \mathrm{tha}^{-1}+\mathrm{RDF}$ & 1.23 & 4.42 & 5.82 & 3.46 & 1.03 & 0.95 & 4.87 & 5.94 & 3.83 & 1.09 \\
\hline $\mathrm{M}_{3}$ - Vermicompost $1.5 \mathrm{tha}^{-1}+\mathrm{RDF}$ & 1.21 & 4.16 & 5.22 & 3.15 & 0.96 & 0.87 & 4.47 & 5.62 & 3.30 & 1.01 \\
\hline $\mathrm{M}_{4^{-}}$Green manuring $+\mathrm{RDF}$ & 1.28 & 4.70 & 5.86 & 3.30 & 1.02 & 0.92 & 4.90 & 5.71 & 3.63 & 1.05 \\
\hline $\mathrm{SEm} \pm$ & 0.053 & 0.180 & 0.207 & 0.158 & 0.034 & 0.032 & 0.143 & 0.285 & 0.109 & 0.042 \\
\hline $\mathrm{CD}(\mathrm{P}: 0.05)$ & 0.16 & 0.56 & 0.64 & 0.46 & 0.10 & 0.10 & 0.44 & 0.88 & 0.34 & 0.13 \\
\hline $\mathrm{CV}(\%)$ & 10.5 & 9.9 & 8.9 & 10.7 & 7.9 & 8.3 & 7.2 & 11.8 & 7.3 & 9.6 \\
\hline
\end{tabular}

Fe uptake by rice

Data on Fe uptake by rice at different growth stages due to various treatments are presented in (Table 3). The treatments those received organics along with the RDF $\left(\mathrm{M}_{2}\right.$, $\mathrm{M}_{3}$ and $\mathrm{M}_{4}$ ) significantly increased the Fe uptake at 30, 60 and 90 DAT over the treatment that received RDF alone $\left(\mathrm{M}_{1}\right)$ and were on par with each other during both the years of study. These results were in agreement with the findings of Sriramachandrasekharan (2001) who reported the highest Fe uptake with green manuring of Sesbania aculeata. Fe uptake by rice grain and straw also followed the same trend except by straw in 2012 kharif where $\mathrm{M}_{2}$ was significantly superior to $\mathrm{M}_{3}$. Easy availability of $\mathrm{Fe}$ in organics during mineralization might have increased its uptake by rice due to increased plant height, leaf area, straw and grain yield.
Mn uptake by rice

Data on Mn uptake by rice at different growth stages due to various treatments are presented in (Table 4) which showed significant variations on Mn uptake during both the years of study. On going through the data, it was evident that irrespective of growth stage of rice $\mathrm{Mn}$ uptake by rice was significantly increased in treatments $\mathrm{M}_{2}, \mathrm{M}_{3}$ and $\mathrm{M}_{4}$ over $\mathrm{M}_{1}$ treatment at all growth stages of rice during both seasons of study. At all growth stages the uptake of Mn by rice in treatments $\mathrm{M}_{2}$ and $\mathrm{M}_{4}$ were on par with each other. The availability of $\mathrm{N}$ in soil treated with organic manures was high which might had increased the availability of Mn in soil thereby plant uptake. These results were supported by Das (2000) who reported the interaction between Mn and available $\mathrm{N}$ was found to be positive.

Table 4 Influence of organics on manganese uptake $\left(\mathrm{kg} \mathrm{ha}^{-1}\right)$ at different growth periods of rice

\begin{tabular}{|c|c|c|c|c|c|c|c|c|c|c|}
\hline \multirow[b]{2}{*}{ Treatment } & \multicolumn{5}{|c|}{$2011-2012$} & \multicolumn{5}{|c|}{$2012-2013$} \\
\hline & $\begin{array}{c}30 \\
\text { DAT }\end{array}$ & $\begin{array}{c}60 \\
\text { DAT }\end{array}$ & $\begin{array}{c}90 \\
\text { DAT }\end{array}$ & Straw & Grain & $\begin{array}{c}30 \\
\text { DAT }\end{array}$ & $\begin{array}{c}60 \\
\text { DAT }\end{array}$ & $\begin{array}{c}90 \\
\text { DAT }\end{array}$ & Straw & Grain \\
\hline $\mathrm{M}_{1}-\mathrm{RDF}$ (Control) & 0.297 & 1.215 & 1.464 & 0.921 & 0.202 & 0.264 & 1.392 & 1.719 & 1.042 & 0.162 \\
\hline $\mathrm{M}_{2}-\mathrm{FYM} 10 \mathrm{tha} \mathrm{h}^{-1}+\mathrm{RDF}$ & 0.448 & 1.526 & 2.092 & 1.210 & 0.285 & 0.385 & 1.878 & 2.287 & 1.472 & 0.238 \\
\hline $\mathrm{M}_{3}$ - Vermicompost $1.5 \mathrm{tha}^{-1}+\mathrm{RDF}$ & 0.379 & 1.512 & 1.743 & 1.084 & 0.249 & 0.346 & 1.800 & 2.206 & 1.312 & 0.202 \\
\hline $\mathrm{M}_{4^{-}}$Green manuring $+\mathrm{RDF}$ & 0.535 & 1.563 & 2.050 & 1.276 & 0.286 & 0.372 & 1.925 & 2.258 & 1.328 & 0.222 \\
\hline SEm \pm & 0.017 & 0.073 & 0.070 & 0.044 & 0.010 & 0.014 & 0.076 & 0.117 & 0.052 & 0.013 \\
\hline $\mathrm{CD}(\mathrm{P}: 0.05)$ & 0.052 & 0.226 & 0.216 & 0.135 & 0.032 & 0.044 & 0.233 & 0.359 & 0.161 & 0.039 \\
\hline $\mathrm{CV}(\%)$ & 9.0 & 11.3 & 8.5 & 8.7 & 9.1 & 9.2 & 9.7 & 12.3 & 9.1 & 13.8 \\
\hline
\end{tabular}

The highest Mn uptake by rice grain $\left(0.286 \mathrm{~kg} \mathrm{ha}^{-1}\right)$ and straw $\left(1.276 \mathrm{~kg} \mathrm{ha}^{-1}\right)$ was recorded in the treatment $\mathrm{M}_{4}$ followed by $M_{2}$ during 2011. Whereas, in 2012, maximum
(0.238 and $1.472 \mathrm{~kg} \mathrm{ha}^{-1}$ by grain and straw, respectively) was recorded in the treatment $\mathrm{M}_{2}$ followed by $\mathrm{M}_{4}$. These results were in close conformity with the findings of 
Sriramachandrasekharan (2001) who reported the highest Mn uptake with green manuring of Sesbania aculeata. There were ample evidences that uptake of $\mathrm{Mn}$ is metabolically mediated (More 1972).

Table 5 Influence of organics on copper uptake $\left(\mathrm{g} \mathrm{ha}^{-1}\right)$ at different growth periods of rice

\begin{tabular}{|c|c|c|c|c|c|c|c|c|c|c|}
\hline \multirow[b]{2}{*}{ Treatment } & \multicolumn{5}{|c|}{$2011-2012$} & \multicolumn{5}{|c|}{$2012-2013$} \\
\hline & $\begin{array}{c}30 \\
\text { DAT }\end{array}$ & $\begin{array}{c}60 \\
\text { DAT }\end{array}$ & $\begin{array}{c}90 \\
\text { DAT }\end{array}$ & Straw & Grain & $\begin{array}{c}30 \\
\text { DAT }\end{array}$ & $\begin{array}{c}60 \\
\text { DAT }\end{array}$ & $\begin{array}{c}90 \\
\text { DAT }\end{array}$ & Straw & Grain \\
\hline $\mathrm{M}_{1}-\mathrm{RDF}$ (Control) & 20.3 & 83.5 & 77.7 & 39.0 & 10.6 & 15.1 & 43.3 & 38.4 & 15.0 & 8.9 \\
\hline $\mathrm{M}_{2}-\mathrm{FYM} 10 \mathrm{tha}{ }^{-1}+\mathrm{RDF}$ & 32.6 & 117.1 & 118.4 & 53.9 & 15.6 & 20.1 & 61.4 & 53.0 & 21.2 & 11.8 \\
\hline $\mathrm{M}_{3}$ - Vermicompost $1.5 \mathrm{tha}^{-1}+\mathrm{RDF}$ & 28.5 & 109.3 & 103.3 & 51.5 & 14.7 & 19.8 & 57.9 & 58.3 & 22.3 & 11.3 \\
\hline $\mathrm{M}_{4}$ - Green manuring $+\mathrm{RDF}$ & 33.9 & 117.6 & 111.8 & 61.1 & 16.1 & 19.6 & 59.1 & 53.0 & 20.6 & 11.8 \\
\hline $\mathrm{SEm} \pm$ & 1.57 & 4.56 & 4.51 & 2.26 & 0.60 & 0.94 & 2.06 & 1.65 & 0.74 & 0.46 \\
\hline CD (P: 0.05) & 4.8 & 14.1 & 13.9 & 6.9 & 1.8 & 2.9 & 6.3 & 5.1 & 2.3 & 1.4 \\
\hline $\mathrm{CV}(\%)$ & 12.2 & 9.5 & 9.8 & 9.8 & 9.4 & 11.3 & 8.3 & 7.3 & 8.4 & 9.3 \\
\hline
\end{tabular}

$\mathrm{Cu}$ uptake by rice

Data on $\mathrm{Cu}$ uptake by rice at different growth stages pertaining to various treatments are presented in (Table 5). A critical observation of the data revealed significant variation in $\mathrm{Cu}$ uptake by rice at 30,60, 90 DAT and by straw and grain during both the years of experimentation. The significantly higher $\mathrm{Cu}$ uptake by rice was recorded with organic amended treatments viz. $\mathrm{M}_{2}, \mathrm{M}_{3}$ and $\mathrm{M}_{4}$ over $\mathrm{M}_{1}$ during both the years of study. The $\mathrm{Cu}$ uptake by rice at all stages was on par in treatments $\mathrm{M}_{2}$ and $\mathrm{M}_{4}$. The highest $\mathrm{Cu}$ uptake by rice at 30,60 and 90 DAT was recorded in $\mathrm{M}_{2}$ (application of FYM along with RDF) with 20.1, 61.4 and
53.0 $\mathrm{g} \mathrm{ha}^{-1}$, respectively during $2012 . \mathrm{Cu}$ uptake by grain $\left(11.8 \mathrm{~g} \mathrm{ha}^{-1}\right)$ and straw $\left(21.2 \mathrm{~g} \mathrm{ha}^{-1}\right)$ also followed the same trend during second year but maximum was recorded in the treatment $\mathrm{M}_{4}$ (16.1 and $61.1 \mathrm{~g} \mathrm{ha}^{-1}$ by grain and straw, respectively) during first year. Das and Mandal (1986) reported that the uptake of $\mathrm{Cu}$ by the rice root, straw and grains was found to be more in the rice plants grown under waterlogged condition. The higher $\mathrm{Cu}$ uptake by the different plant parts of rice under waterlogged condition could be explained due to favourable chemical environment of the root medium leading to higher root proliferation and nutrient absorption by the rice under healthy reducing conditions.

Table 6 Influence of organics on zinc uptake $\left(\mathrm{g} \mathrm{ha}^{-1}\right)$ at different growth periods of rice

\begin{tabular}{cccccccccccc}
\hline \multirow{2}{*}{ Treatment } & \multicolumn{4}{c}{$2011-2012$} & \multicolumn{4}{c}{$2012-2013$} \\
\cline { 2 - 11 } & 30 & 60 & 90 & \multirow{2}{*}{ Straw } & \multirow{2}{*}{ Grain } & 30 & 60 & 90 & \multirow{2}{*}{ Straw } & \multirow{2}{*}{ Grain } \\
\hline $\mathrm{M}_{1}$ - RDF (Control) & 76.1 & 288.4 & 289.2 & 142.3 & 118.5 & 61.5 & 303.9 & 385.8 & 103.2 & 125.3 \\
$\mathrm{M}_{2}$ - FYM 10t ha ${ }^{-1}+$ RDF & 117.1 & 419.8 & 426.1 & 183.5 & 183.9 & 86.9 & 427.4 & 519.7 & 156.8 & 167.1 \\
$\mathrm{M}_{3}$ - Vermicompost 1.5t ha ${ }^{-1}+\mathrm{RDF}$ & 106.9 & 378.1 & 380.2 & 175.2 & 146.9 & 79.9 & 361.3 & 466.3 & 137.1 & 154.9 \\
$\mathrm{M}_{4}$ - Green manuring + RDF & 114.0 & 395.0 & 405.6 & 182.4 & 181.1 & 83.9 & 413.1 & 495.5 & 159.2 & 173.1 \\
SEm \pm & 3.52 & 14.59 & 15.29 & 7.01 & 8.85 & 1.77 & 12.32 & 25.22 & 5.36 & 4.96 \\
CD (P: 0.05) & 10.8 & 45.0 & 47.1 & 21.6 & 27.3 & 5.5 & 38.0 & 77.7 & 16.5 & 15.3 \\
CV (\%) & 7.6 & 8.8 & 9.1 & 9.2 & 12.6 & 5.1 & 7.3 & 12.1 & 8.6 & 7.1 \\
\hline
\end{tabular}

\section{Zn uptake by rice}

Data pertaining to effect of organics and inorganics on $\mathrm{Zn}$ uptake by rice at different stages presented in (Table 6) revealed that there was a significant variation during both the years of experimentations. It was obvious from the data the highest $\mathrm{Zn}$ uptake of rice was observed in the treatment $\mathrm{M}_{2}$ with $117.1,419.8$ and $426.1 \mathrm{~g} \mathrm{ha}^{-1}$ followed by $\mathrm{M}_{4}$ with 114.0, 395.0 and $405.6 \mathrm{~g} \mathrm{ha}^{-1}$ at 30,60 and 90 DAT of rice respectively during first year of the study. Similar trend was observed in case of rice grain and straw during 2011. Whereas, during second year the highest $\mathrm{Zn}$ uptake by grain and straw was recorded by the treatment $\mathrm{M}_{4}$ (159.2 and $\left.173.1 \mathrm{~g} \mathrm{ha}^{-1}\right)$ followed by $\mathrm{M}_{2}$ (156.8 and $\left.167.1 \mathrm{~g} \mathrm{ha}^{-1}\right)$. Dahdouh et al. (1999) found that organic manures played an important role in nutrients solubility and activated physiological and biochemical processes in plant which led to increase the plant growth and nutrient uptake. Application of organics proved to increase the $\mathrm{Zn}$ uptake significantly by rice straw and grain as against the application of RDF alone $\left(\mathrm{M}_{1}\right)$. Application of organics increased the $\mathrm{Zn}$ uptake which might be due to greater availability of micronutrients in the soil as well as the organics. In majority of studies, there was a significant positive relationship (De et al. 1994) between organic matter and available $\mathrm{Zn}$ in soils.

From the results of the investigation it was observed that application of manures along with $100 \%$ NPK $\left(\mathrm{M}_{2}, \mathrm{M}_{3}\right.$ and $\mathrm{M}_{4}$ ) significantly increased the $\mathrm{Ca}$ and $\mathrm{Mg}$ as well as micro nutrient uptake over the treatment that received 100\% NPK alone $\left(\mathrm{M}_{1}\right)$. Among the organics the highest $\mathrm{Ca}$ and $\mathrm{Mg}$ uptake by plant was recorded with the application of $100 \%$ NPK along with 10t FYM ha ${ }^{-1}$ followed by $100 \%$ $\mathrm{NPK}+$ Green manure in situ. 


\section{Secondary and Micro Nutrient Uptake by Rice at various Growth Periods \\ LITERATURE CITED}

Bellakki M A and Badanur V P. 1997. Long-term effect of integrated nutrient management on properties of Vertisol under dryland agriculture. Journal of the Indian Society of Soil Science 45: 438-442.

Brady N C. 1990. The nature and properties of soil (10 ${ }^{\text {th }}$ Edition). Macmillan Publishing Co. New York.

Chander G, Verma T S and Sharma S. 2007. Influence of boron and FYM on available B \& exchangeable Ca and their removal by cauliflower in the boron deficient soils of Himachal Pradesh. Journal of the Indian Society of Soil Science 55(1): $62-66$.

Dahdouh S M A, Fatma A A and Salem F M. 1999. Effect of organic manure and foliar application of some macro and micro nutrients on wheat. Journal of Agricultural Research 26(2): 445-456.

Das D K and Mandal L N. 1986. In: Micronutrients: Their behaviour in soils and plants (Eds) D. K. Das). Kalyani Publishers, New Delhi-110002. 47-126.

Das P K, Jena M K and Sahoo K C. 2002. Effect of integrated application of vermicompost and chemical fertilizer on growth and yield of paddy in red soil of south eastern ghat zone of Orissa. Environment and Ecology 20(1): 13-15.

De B, De S K and Das D K. 1994. Indian Agriculture 38: 201-205.

Hesse P R. 1971. A text book of soil chemical analysis. John Murry Publishers Ltd., London. UK. pp 528.

Hussain M A, Ogunlela V B Ramalan A A and Falaki A M. 2001. Growth and development of maize (Zea mays) in response to different levels of nitrogen phosphorus and irrigation. Crop Research 22: 141-149.

Jadhav A D, Talashilkar S C and Powar A G. 1997. Influence of conjunctive use of FYM, vermicompost and urea on growth and nutrient uptake in rice. Journal of Maharashtra Agricultural Universities 22(2): 249-250.

Karmakar S, Mittra B N and Ghosh B C. 2010. Enriched coal ash utilization for augmenting production of rice under acid lateritic soil. Coal Combustion and Gasification Products 2: 45-50.

Lindsay and Norvell W A. 1978. Development of DTPA soil test for zinc, iron, manganese and copper. Soil Science Society of American Journal 45: 378-385.

More D P. 1972. Micronutrients in agriculture. (Eds) Mortvedt J. J. SSSA, Madison, WI. pp 171-198.

Olsen S R, Code C L, Watanable F S and Dean L A. 1954. Estimation of available phosphorus in soils by extraction with sodium bicarbonate. United States Development Agency Circular Number 939.

Pattanayak S K, Mishra K N, Jena M K and Nayak R K. 2001. Evaluation of green manure crops fertilized with various phosphorus sources and their effect on subsequent rice crop. Journal of the Indian Society of Soil Science 49(2): 285291.

Singh M, Singh V P and Reddy K S. 2001a. Effect of integrated use of fertilizer nitrogen and farm yard manure or green manure on transformation of $\mathrm{N}, \mathrm{K}$ and $\mathrm{S}$ and productivity of rice-wheat system on a Vertisol. Journal of the Indian Society of Soil Science 49(3): 430-435.

Sriramachandrasekharan M V. 2001. Effect of organic manures on the nutrient uptake, yield and nutrient use efficiency in lowland rice. Journal of Ecobiology 13(2): 143-147.

Subbiah B V and Asija C L. 1956. A rapid procedure for the estimation of available nitrogen in soils. Current Science 25: 259-260.

Tandon H L S. 2000. Fertilizers, organic manures, recyclable wastes and biofertlizers - components of integrated plant nutrition - fertilizer development and consultation organization. 204-204 A Bhanot Corner, 1-2 Pamposh Enclave New Delhi-110048, India.

Watanabe F S and Olsen S R. 1965. Test of ascorbic acid method fordetermining phosphorous in water and sodium bicarbonate extracts of soil. Soil Science Society of American Journal 29: 677-678. 